\title{
Structural Performance of Innovative Lean Duplex Stainless Steel Built-UP Columns under Various Loading
}

\author{
Hima M S \\ PG Student, \\ Structural Engineering and Construction Management, \\ Department of Civil Engineering. \\ Sree Narayana Gurukulam College of Engineering \\ Kadayiruppu P.O, Kolenchery
}

\author{
Samithamol Salim \\ Assistant Professor \\ Department of Civil Engineering. \\ Sree Narayana Gurukulam College of Engineering \\ Kadayiruppu P.O, Kolenchery
}

\begin{abstract}
The use of cold-formed steel structures including built-up sections has increased in recent years, for their excellent structural behaviors. The Lean Duplex Stainless Steel (LDSS), which is a category of stainless steel is becoming popular as a structural member because of its increased corrosion resistance and durability compared with that of steel. When compared to other construction materials, the LDSS has many unique properties that are advantageous not only from a corrosion view point, but also from a strength and safety as well. These LDSS may be used as primary structures for compression members of trusses or built-up columns due to varieties of advantages such as high strength to weight ratio, ease of fabrication, no need of protective coatings and they can be fully recycled after a useful life. This study presents an investigation on the LDSS built-up columns of rectangular, $I, T$ and $Z$ shaped sections under the axial loading, eccentric loading for various eccentricities and lateral load resisting performance. In addition, a parametric study is carried out to optimize the best models in various loading conditions and comparing the LDSS built-up section with conventional steel. The finite element models of LDSS built-up columns are developed using ANSYS 16.1 WORKBENCH in order to investigate the behavior of various built-up columns. This study considers the eccentric loadings at $25 \%, 50 \%$ and $\mathbf{7 5 \%}$ eccentricities of the rectangular, $I, T$ and $Z$ shaped LDSS built-up columns.
\end{abstract}

Keywords-Built-up columns; axial loading; eccentric loading; lateral loading

\section{INTRODUCTION}

Cold formed steel (CFS) built-up members have a traditional application in civil engineering for compressed structural elements, mostly as columns and members of lat-tice structures to carry heavier loads and over longer spans when a single individual section is insufficient. Built-up of normal CFS into new member with higher strength can be produced efficiently by attaching the steel. By using cold-formed Lean Duplex Stainless Steel (LDSS) structures in the building construction industry it can provide more potential benefits including high strength to weight ratio, rapid constructability and ease of transportability and more over resistance to corrosion. So there is a scope for using the LDSS as built-up columns to improve the structural stability of buildings.

Duplex stainless steels are called "duplex" because they have a two phase micro-structure consisting of approximately equal proportion of austenite and ferrite. Stain-less steel is more expensive than standard grades of steel but it has greater resistance to corrosion, needs low maintenance and has no need for painting or other protective coatings. These factors make stainless steel can be more economically viable once ser-vice life and life cycle costs are considered. In the last few years, significant progress has been made on the behavior of LDSS structural members, including material properties, beams, columns, beam-columns, plate girders and LDSS bolted connections. Built-up section can simply gain higher stability and capacity due to double of standard section, produce greater cross-section properties, the symmetry of built-up section can eliminate the eccentricity between the shear and the gravity center of single section consequently eliminate certain buckling effects

\section{LITERATURE STUDY}

Y. Huang et al. conducted an experimental study on pinended cold-formed LDSS columns compressed between pinned ends to determine the axial load carrying capacity. Rossi et al. presented a discussion on the use of stainless steel in constructions in view of sustainability. Dabaon et al. presents an experimental investigation on behavior and design of builtup cold-formed steel section battened columns. Dobric et al. conducted an experimental study on the Resistance of coldformed built-up stainless steel columns and addresses their flexural buckling capacity about the minor principal axis.

\section{OBJECTIVES}

1. To investigate the axial loading performance of various built- up sections.

2. To analyze the eccentric loading for various eccentricities in various built- up sections.

3. To analyze the lateral resisting performance of lean duplex stainless steel built-up columns.

4. To optimize out of best models.

5. To compare any LDSS built-up column with conventional section.

\section{METHODOLOGY}

In this study, the literature review is done, the modelling of the specimen is done using ANSYS 16.1 WORKBENCH, $\begin{array}{llll}\text { conducting parameter study using ANSYS } & 16.1\end{array}$ WORKBENCH and the interpretation of results are done. 


\section{FINITE ELEMNT MODELLING}

A column of length $900 \mathrm{~mm}$, width $50 \mathrm{~mm}$ and depth 70 $\mathrm{mm}$ with thickness $2.5 \mathrm{~mm}$ is used to construct the various LDSS built-up columns. Three numbers of columns with same dimensions are used to model the various LDSS built-up columns. Built-up columns of four different shapes such as are rectangular section, I section, $\mathrm{T}$ section and $\mathrm{Z}$ sections are proposed in this study. Fig. 1 to Fig. 4 shows the model of the various LDSS built-up specimens used in the study.
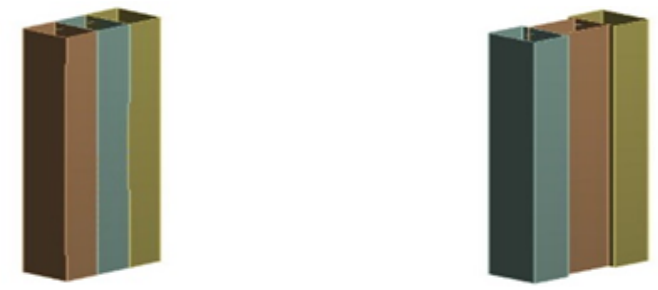

Fig.1 Rectangular LDSS column Fig.2 I LDSS built-up column
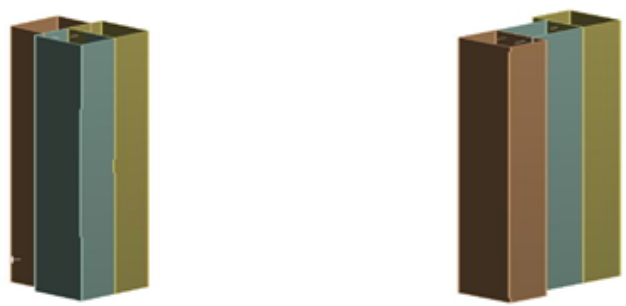

Fig.3 T LDSS built-up column Fig.4 Z LDSS built-up column

\section{A. General Information}

ANSYS 16.1 WORKBENCH software is used to perform the analysis of various built-up columns. The aim is used to create various LDSS built-up columns. Built-up columns of four different shapes are proposed in this study. They are rectangular section, I section, $\mathrm{T}$ section and $\mathrm{Z}$ sections. The bolted interconnections were designed with steel bolts.

\section{B. Material Properties}

For the specimens of Y.Huang et al.[1], the static $0.2 \%$ proof stress $(\sigma 0.2)$ is $635 \mathrm{MPa}$, static tensile strength $(\sigma \mathrm{u})$ is $756 \mathrm{MPa}$, initial Young's modulus (Eo) is $198 \mathrm{MPa}$ and poisons ratio is 0.3 . The bolted interconnections were designed with steel bolts M5, class 5.8. The spacing between the bolt centers is $95 \mathrm{~mm}$. The bolted interconnection corresponds to the shear connection category A, according to EN 1993-1-8. The nominal mechanical properties of bolts are yield strength with $400 \mathrm{~N} / \mathrm{mm}^{2}$ and ultimate tensile strength $500 \mathrm{~N} / \mathrm{mm}^{2}$.

\section{Geometry}

Geometrical details of the column specimen used in the study are given in Table 1

TABLE 1. MEASURED SPECIMEN DIMENSIONS FOR
\begin{tabular}{|c|c|}
\hline CL900 \\
\hline Specimen & CL900 \\
\hline Depth (mm) & 70 \\
\hline Width (mm) & 50 \\
\hline Thickness (mm) & 2.5 \\
\hline Outer radius (mm) & 4.2 \\
\hline Inner radius (mm) & 1 \\
\hline
\end{tabular}

\section{Element Mesh}

All the LDSS built-up columns were modelled with a similar mesh size. Shell element were used to model the various LDSS built-up column. Across the length and width of the column, a mesh size of $5 \mathrm{~mm} \times 5 \mathrm{~mm}$ was used.

\section{E. Boundary Conditions}

The loading conditions were applied using the boundary conditions of each cross-section. The LDSS built-up columns were compressed between the pinned ends. A pinned support allows rotation but not translation which means it resist horizontal and vertical forces but not a moment.

\section{G. Moment of Inertia}

Table 2 shows the moment of inertia of various built-up columns.

TABLE 1. MEASURED SPECIMEN DIMENSIONS FOR

\begin{tabular}{|c|c|}
\hline \multicolumn{2}{|c|}{ CL900 } \\
\hline Specimen & CL900 \\
\hline Depth (mm) & 70 \\
\hline Width (mm) & 50 \\
\hline Thickness (mm) & 2.5 \\
\hline Outer radius (mm) & 4.2 \\
\hline Inner radius (mm) & 1 \\
\hline
\end{tabular}

\section{F. Element Mesh}

All the LDSS built-up columns were modelled with a similar mesh size. Shell element were used to model the various LDSS built-up column. Across the length and width of the column, a mesh size of $5 \mathrm{~mm}$ x $5 \mathrm{~mm}$ was used.

\section{G. Boundary Conditions}

The loading conditions were applied using the boundary conditions of each cross-section. The LDSS built-up columns were compressed between the pinned ends. A pinned support allows rotation but not translation which means it resist horizontal and vertical forces but not a moment.

\section{G. Moment of Inertia}

Table 2 shows the moment of inertia of various built-up columns.

TABLE 2. MOMENT OF INERTIA OF LDSS BUILT-UP COLUMNS

\begin{tabular}{|l|c|c|}
\hline \multicolumn{1}{|c|}{ Built-up columns } & $\begin{array}{c}\text { Moment of inertia, } \\
\mathbf{I}_{\mathbf{X X}}\left(\mathbf{m m}^{\mathbf{4}}\right)\end{array}$ & $\begin{array}{c}\text { Moment of Inertia, } \\
\mathbf{I}_{\mathbf{Y Y}}\left(\mathbf{m m}^{\mathbf{4}}\right)\end{array}$ \\
\hline $\begin{array}{l}\text { Rectangular built-up } \\
\text { column }\end{array}$ & 2187500 & 19687500 \\
\hline I built-up column & 28087500 & 3587500 \\
\hline T built-up column & 42887500 & 2190766 \\
\hline Z built-up column & 28087500 & 4287500 \\
\hline
\end{tabular}

\section{RESULTS AND DISCUSSION}

\section{A. Axial Loading}

The axial loading capacity of LDSS built-up columns was determined from FE analysis. Table 3 shows the maximum load and deflection of axially loaded various LDSS built-up columns and Fig. 5 shows the comparison of axial loading performed in various built-up columns. 
TABLE 3. MAXIMUM LOAD AND DEFLECTION OF AXIALLY LOADED BUILT-UP COLUMNS

\begin{tabular}{|l|c|c|}
\hline \multicolumn{1}{|c|}{ Built-up columns } & Deflection (mm) & Load(kN) \\
\hline Rectangular built-up column & 3.94 & 889 \\
\hline I built-up column & 3.43 & 862 \\
\hline T built-up column & 2.89 & 1126 \\
\hline Z built-up column & 2.86 & 941 \\
\hline
\end{tabular}

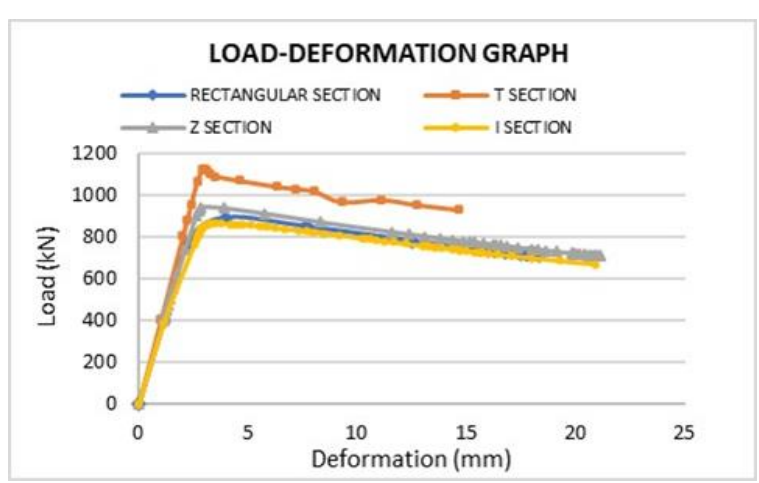

Fig. 5 LDSS built-up columns loaded axially

From Fig. 5, the axial load carrying capacity of the LDSS T section increased upto $26.7 \%$ with LDSS rectangular section, $30.6 \%$ with LDSS I section and $19.6 \%$ with that of LDSS Z section.

\section{B. Eccentric Loading}

The eccentric loading capacity of LDSS built-up columns was determined from FE analysis. Table 3 to 5 shows the maximum load and deflection of eccentrically loaded various LDSS built-up columns at various eccentricities along $X$ and $\mathrm{Y}$ directions and Fig. 6 to Fig.11 shows the comparison of eccentric loading performed in various built-up columns.

TABLE 4. MAXIMUM LOAD AND DEFLECTION OF ECCENTRICALLY LOADED BUILT-UP COLUMNS AT $25 \%$ IN Z AND Y DIRECTION

\begin{tabular}{|l|c|c|c|c|}
\hline \multirow{2}{*}{ Built-up columns } & \multicolumn{2}{|c|}{$\begin{array}{c}\text { Eccentric load at 25\% } \\
\text { in Z direction }\end{array}$} & $\begin{array}{c}\text { Eccentric load at 25\% in } \\
\text { x direction }\end{array}$ \\
\cline { 2 - 5 } & $\begin{array}{c}\text { Deflection } \\
(\mathbf{m m})\end{array}$ & Load $(\boldsymbol{k N})$ & $\begin{array}{c}\text { Deflection } \\
(\mathbf{m m})\end{array}$ & Load( $\boldsymbol{k N})$ \\
\hline $\begin{array}{l}\text { Rectangular built- } \\
\text { up column }\end{array}$ & 3.94 & 889.08 & 3.28 & 866.65 \\
\hline I built-up column & 3.26 & 861.45 & 5.87 & 754.78 \\
\hline T built-up column & 2.89 & 1126.6 & 4.98 & 89.29 \\
\hline Z built-up column & 2.86 & 941.87 & 4.2 & 813.89 \\
\hline
\end{tabular}

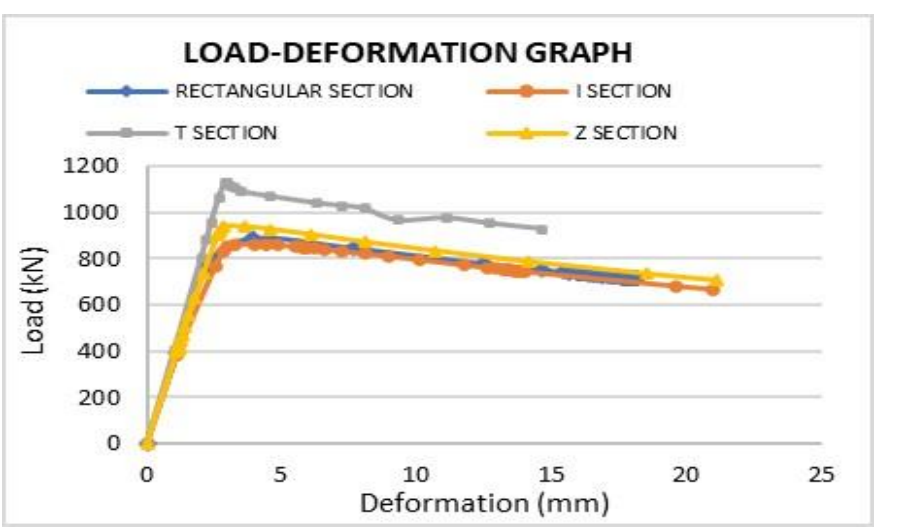

Fig. 6 LDSS built-up columns loaded eccentrically at $25 \%$ in $\mathrm{Z}$ direction
From Fig. 6, the load carrying capacity at an eccentricity of $25 \%$ in $\mathrm{Z}$ direction of the LDSS T-section increased upto $26.7 \%$ with LDSS rectangular section, $30.77 \%$ with LDSS Isection and $19.6 \%$ with that of LDSS Z-section.

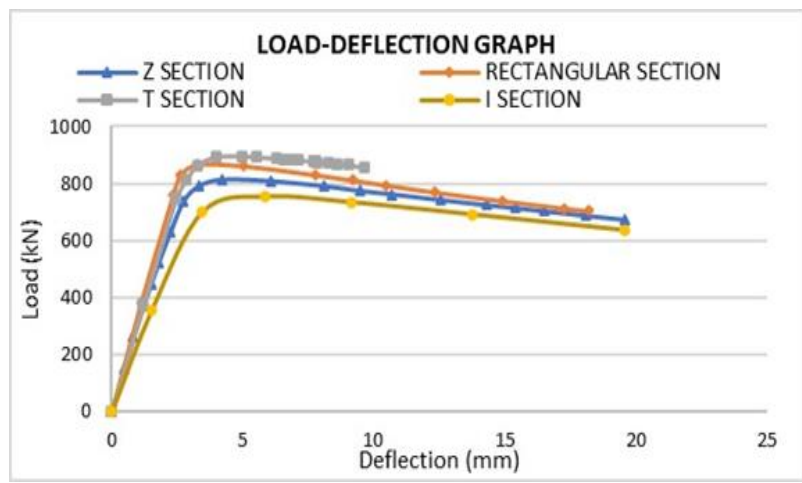

Fig. 7 LDSS built-up columns loaded eccentrically at $25 \%$ in X direction

From Fig. 7, the load carrying capacity at an eccentricity of $25 \%$ in $\mathrm{X}$ direction of the LDSS T-section increased upto $3.4 \%$ with LDSS rectangular section, $18.7 \%$ with LDSS Isection and $6.5 \%$ with that of LDSS Z-section.

TABLE 5. MAXIMUM LOAD AND DEFLECTION OF ECCENTRICALLY LOADED BUILT-UP COLUMNS AT $50 \%$ IN Z AND X DIRECTION

\begin{tabular}{|l|c|c|c|c|}
\hline \multicolumn{1}{|c|}{$\begin{array}{c}\text { Built-up } \\
\text { columns }\end{array}$} & \multicolumn{2}{|c|}{$\begin{array}{c}\text { Eccentric load at 50\% in } \\
\text { Z direction }\end{array}$} & \multicolumn{2}{|c|}{$\begin{array}{c}\text { Eccentric load at 50\% in } \\
\text { X direction }\end{array}$} \\
\cline { 2 - 5 } & $\begin{array}{c}\text { Deflection } \\
(\mathbf{m m})\end{array}$ & Load $(\boldsymbol{k N})$ & $\begin{array}{c}\text { Deflection } \\
(\mathbf{m m})\end{array}$ & Load(kN) \\
\hline $\begin{array}{l}\text { Rectangular } \\
\text { built-up column }\end{array}$ & 2.94 & 888.13 & 6.03 & 739.5 \\
\hline $\begin{array}{l}\text { I built-up } \\
\text { column }\end{array}$ & 3.67 & 862.28 & 6.46 & 671.31 \\
\hline $\begin{array}{l}\mathrm{T} \text { built-up } \\
\text { column }\end{array}$ & 2.95 & 1128.1 & 5.49 & 745.3 \\
\hline $\begin{array}{l}\mathrm{Z} \text { built-up } \\
\text { column }\end{array}$ & 2.95 & 943.41 & 12.76 & 672.45 \\
\hline
\end{tabular}

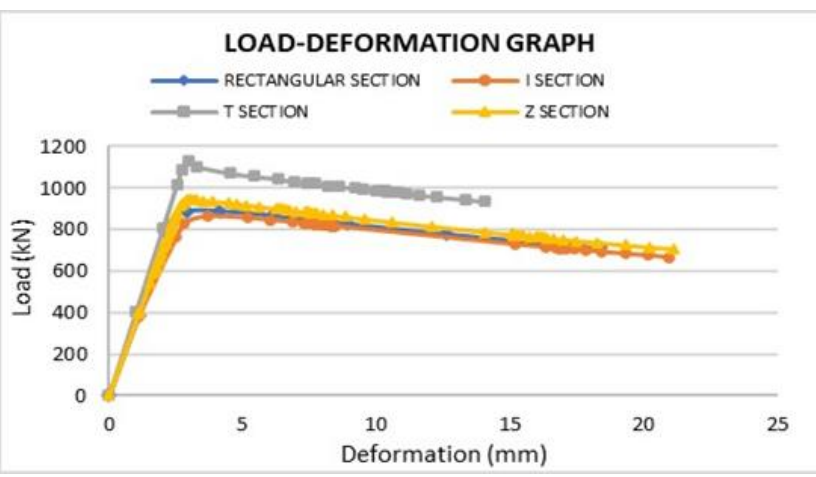

Fig. 8 LDSS built-up columns loaded eccentrically at $50 \%$ in $\mathrm{Z}$ direction

From Fig. 8, the load carrying capacity at an eccentricity of $50 \%$ in $\mathrm{Z}$ direction of the LDSS T-section increased upto $28 \%$ with LDSS rectangular section, $30 \%$ with LDSS I-section and $20 \%$ with that of LDSS Z-section. 


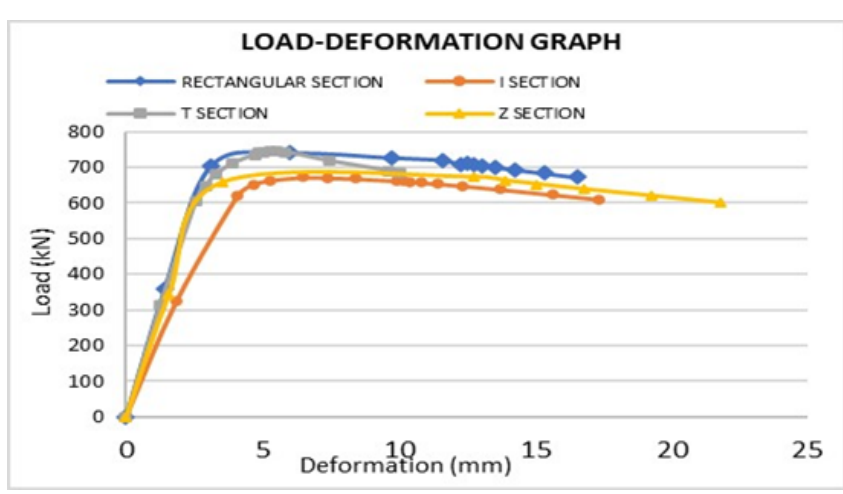

Fig. 9 LDSS built-up columns loaded eccentrically at 50\% in X direction

From Fig. 9, the load carrying capacity at an eccentricity of $50 \%$ in X direction of the LDSS T-section increased upto $1 \%$ with the LDSS rectangular section, $11 \%$ with LDSS I-section and $10 \%$ with that of LDSS Z-section.

TABLE 6. MAXIMUM LOAD AND DEFLECTION OF ECCENTRICALLY LOADED BUILT-UP COLUMNS AT $75 \%$ IN Z AND X DIRECTION

\begin{tabular}{|l|c|c|c|c|}
\hline \multirow{2}{*}{$\begin{array}{c}\text { Built-up } \\
\text { columns }\end{array}$} & \multicolumn{2}{|c|}{$\begin{array}{c}\text { Eccentric load at 75\% in Z } \\
\text { direction }\end{array}$} & \multicolumn{2}{c|}{$\begin{array}{c}\text { Eccentric load at 75\% in } \\
\text { X direction }\end{array}$} \\
\cline { 2 - 5 } & Deflection $(\boldsymbol{m m})$ & Load $(\boldsymbol{k N})$ & $\begin{array}{c}\text { Deflection } \\
(\mathbf{m m})\end{array}$ & Load $(\boldsymbol{k N})$ \\
\hline $\begin{array}{l}\text { Rectangular } \\
\text { built-up } \\
\text { column }\end{array}$ & 3.19 & 889.29 & 8.76 & 677.72 \\
\hline $\begin{array}{l}\text { I built-up } \\
\text { column }\end{array}$ & 4.97 & 855.23 & 9.33 & 603.88 \\
\hline $\begin{array}{l}\mathrm{T} \text { built-up } \\
\text { column }\end{array}$ & 2.96 & 1124.8 & 5.61 & 704.34 \\
\hline $\begin{array}{l}\mathrm{Z} \text { built-up } \\
\text { column }\end{array}$ & 2.86 & 941.87 & 7.19 & 645.07 \\
\hline
\end{tabular}

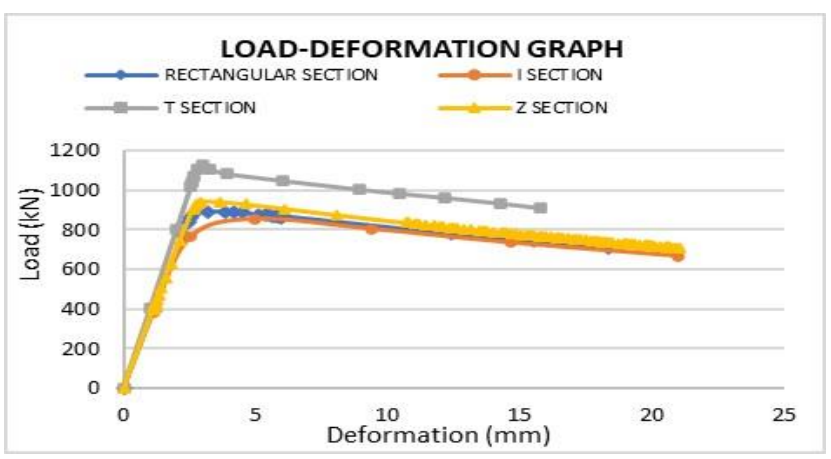

Fig. 10 LDSS built-up columns loaded eccentrically at $75 \%$ in $\mathrm{Z}$ direction

From Fig. 10, The load carrying capacity at an eccentricity of $75 \%$ in $\mathrm{Z}$ direction of the LDSS $\mathrm{T}$ section increased upto $26.4 \%$ with LDSS rectangular section, $31.5 \%$ with LDSS Isection and $19.4 \%$ with that of LDSS Z-section.

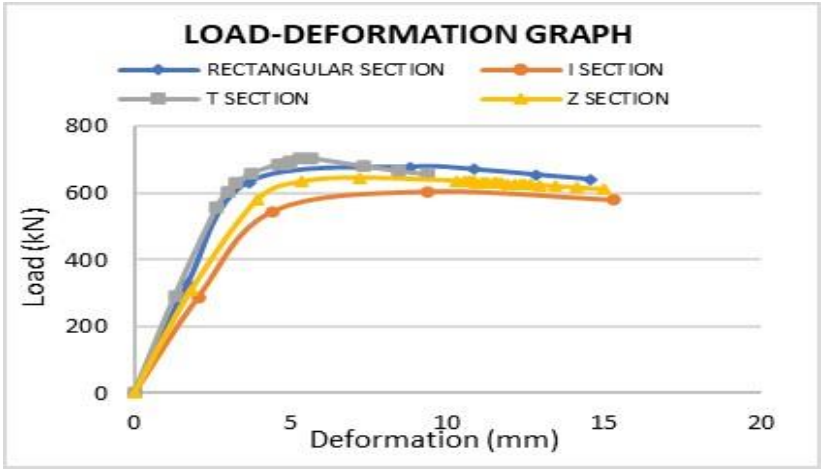

Fig. 11 LDSS built-up columns loaded eccentrically at 75\% in X direction

From Fig. 11, The load carrying capacity at an eccentricity of $75 \%$ in $\mathrm{X}$ direction of the LDSS T-section increased upto $4 \%$ with LDSS rectangular section, $16.6 \%$ with LDSS Isection and $9.2 \%$ with that of LDSS Z-section.

\section{Lateral Loading}

The lateral loading capacity of LDSS built-up columns was determined from FE analysis. Table 7 shows the maximum load and deflection of laterally loaded various LDSS built-up columns and Fig. 12 shows the comparison of axial loading performed in various built-up columns.

\section{TABLE 7. MAXIMUM LOAD AND DEFLECTION OF LATERALLY LOADED BUILT-UP COLUMNS}

\begin{tabular}{|l|c|c|}
\hline \multicolumn{1}{|c|}{ Built-up columns } & Deflection $(\mathbf{m m})$ & Load(kN) \\
\hline Rectangular built-up column & 70.23 & 57.33 \\
\hline I built-up column & 87.81 & 65.72 \\
\hline T built-up column & 100.3 & 62.84 \\
\hline Z built-up column & 87.57 & 63.87 \\
\hline
\end{tabular}

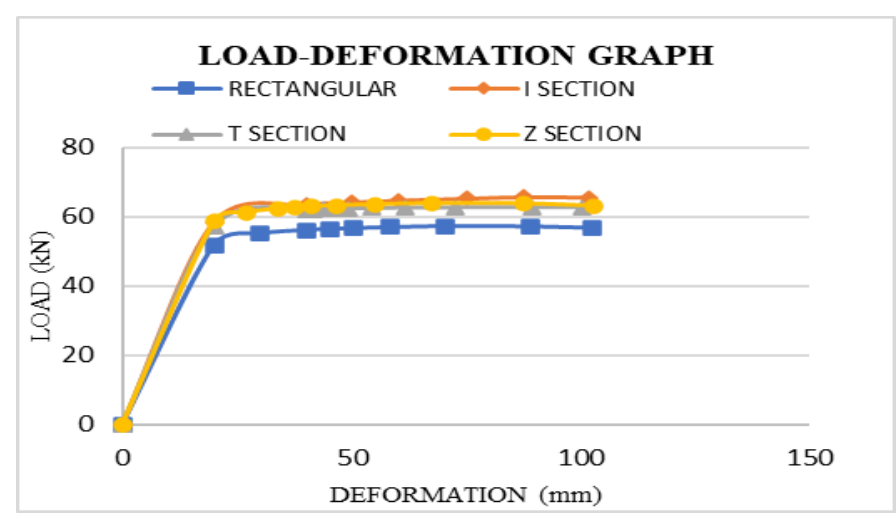

Fig. 12 LDSS built-up columns loaded laterally

From Fig. 12, the lateral load carrying capacity of the LDSS I section increased upto $14.6 \%$ with LDSS rectangular section, $4.5 \%$ with LDSS $\mathrm{T}$ section and $2.8 \%$ with that of LDSS Z section.

D. Comparing I Shaped LDSS Built-Up Columns with ISMB150

As per IS CODE, 808(1989), for a columns section of depth $150 \mathrm{~mm}$, the properties of section are given below in table 8 . Fig.13 shows the model of ISMB150 and Fig. 14 shows the load- deflection values of ISMB150. 
TABLE 8. PROPERTIES OF ISMB150

\begin{tabular}{|l|l|}
\hline Mass $(\mathrm{kg})$ & 15 \\
\hline Sectional area $(\mathrm{cm} 3)$ & 19.1 \\
\hline Depth $(\mathrm{mm})$ & 150 \\
\hline Width $(\mathrm{mm})$ & 75 \\
\hline Web thickness $(\mathrm{mm})$ & 5 \\
\hline Flange thickness $(\mathrm{mm})$ & 8 \\
\hline Moment of inertia, $\mathrm{I}_{\mathrm{XX}}\left(\mathrm{cm}^{4}\right)$ & 718 \\
\hline Moment of inertia, $\mathrm{I}_{\mathrm{YY}}\left(\mathrm{cm}^{4}\right)$ & 46.8 \\
\hline
\end{tabular}

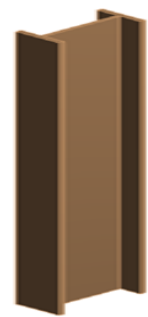

Fig. 13 ISSC 150 modelled in ANSYS 16.1 WORKBENCH

TABLE 9. LOAD AND DEFLECTION OF AXIALLY LOADED ISMB 150

\begin{tabular}{|c|c|}
\hline Deflection (mm) & Load (kN) \\
\hline 0 & 0 \\
\hline 1 & 413.77 \\
\hline 2.01 & 468.29 \\
\hline 2.17 & 468.31 \\
\hline 2.33 & 468.4 \\
\hline 2.39 & 468.4 \\
\hline 2.45 & 468.23 \\
\hline 2.51 & 468.21 \\
\hline 2.6 & 468.04 \\
\hline 2.74 & 467.76 \\
\hline 2.94 & 467.25 \\
\hline 3.25 & 466.26 \\
\hline 3.72 & 464.47 \\
\hline 4.42 & 461.34 \\
\hline 5.95 & 456.01 \\
\hline
\end{tabular}

Fig. 14 Load and deflection of ISMB150

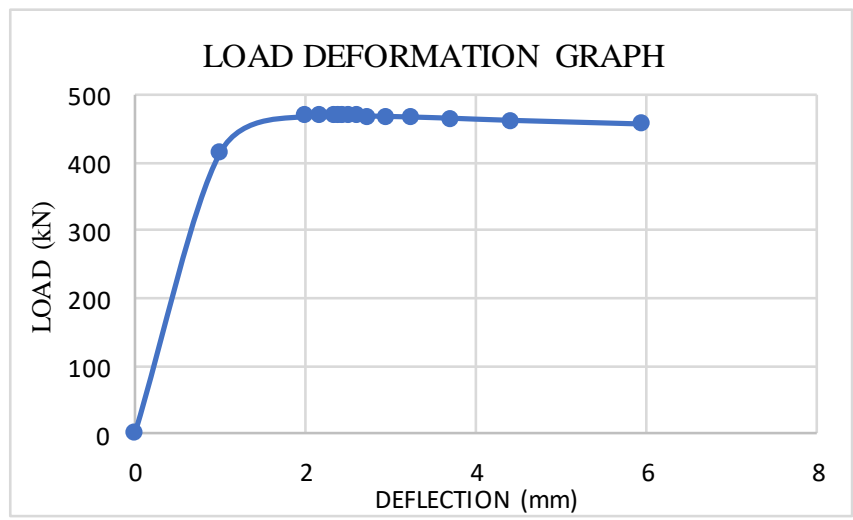

When we compare the I shaped LDSS built-up column with an ISMB150 section, it is found that the axial loading capacity of ISMB150 is very low when compared with I shaped LDSS built-up column. It is observed that the axial load carrying capacity of the LDSS I section has an increment upto $84 \%$ with ISMB150. So the LDSS built -up sections are found to be more efficient in load carrying capacity compared to ISMB150. The mass of ISMB150 IS $15 \mathrm{~kg}$ but the mass of I shaped LDSS built-up column is $12.95 \mathrm{~kg}$. From this it is observed that even though with the low mass the LDSS builtup section can carry more load than that of conventional sections.

\section{SCOPE}

Most of the structures are made of steel. But as the life cycle increases, there is a chance of corrosion. In recent years, a relatively new type of stainless steel, called lean duplex stainless steel of grade EN 1.4162, with structural and economical advantages was developed. It is becoming an attractive choice as a construction material due to its low cost compared to duplex stainless steel, and the strength of the material is comparable with duplex stainless steel. Coldformed lean duplex stainless steel is gaining increasing applications as a construction material serving both architectural and structural needs. By using cold-formed lean duplex stainless steel structures in the building construction industry it can provide potential benefits including high strength to weight ratio, rapid constructability and ease of transportability and more over its resistance to corrosion. So there is a scope for using the lean duplex stainless steel as built-up columns to improve the structural stability of buildings.

\section{CONCLUSION}

The finite element analysis of Lean Duplex Stainless Steel (LDSS) in various built-up section was carried out for studying the structural performance of various LDSS built up sections. Based on the objectives of the project following conclusions were obtained:

- $\quad$ All the LDSS built-up sections considered in the study perform the load carrying capacity in both axial and eccentric loading conditions quite well.

- The behavior of all LDSS built-up sections are similar to each other and there is only a slight variation in the load carrying capacity.

- In the case of axial and eccentric loading in various eccentricities, the $\mathrm{T}$ shaped LDSS built-up section has the maximum axial and eccentric loading compared to other various built-up columns proposed in this study even though it has an unsymmetrical shape with respect to $\mathrm{X}$ axis.

- $\quad$ But in the case of lateral loading, the I shaped built-up column shows the maximum load compared to other LDSS built-up columns.

- The moment of inertia of T shaped LDSS built-up column increased with respect to $\mathrm{X}$ axis when compared with other LDSS built-up columns. More is the moment of inertia, then more is the bending strength and resistance offered by body towards rotation.

- When we compare the LDSS I shaped built-up column with an ISMB 150 section, it is found that, I shaped LDSS built-up column is economical in the case of its 
mass and also it can carry more load and deflection than that of ISMB 150.

- Therefore the use of various shaped LDSS built-up sections can be recommended as it is able to carry the load for which it is designed.

\section{ACKNOWLEDGEMENT}

I am thankful to my guide, Ms. Samithamol Salim, Asst. Professor in Civil Engineering Department of Sree Narayana Gurukulam College of Engineering, Kadayiruppu for her constant encouragement and able guidance. Also I thank my parents, friends etc. for their continuous support in making this work a success.

\section{REFERENCES}

[1] Dabaon, Mohamed, et al. "Experimental investigation of built-up coldformed steel section battened columns." Thin-Walled Structures, Vol. 92, 2015, pp. 137-145.

[2] Dobric, Jelena, et al., "Resistance of cold-formed built-up stainless steel columns-part I: experiment." Journal of Constructional Steel Research, Vol. 145, 2018, pp. 552-572.

[3] Huang, Y, and B. Young, "Tests of pin-ended cold-formed lean duplex stainless steel col-umns." Journal Of Constructional Steel Research, Vol.82, 2013, pp. 203-215.

[4] Rossi, Barbara, "Discussion on the use of stainless steel in constructions in view of sus-tainability." Thin-Walled Structures, Vol83, 2014, pp.18 